\title{
POLITIK ANGGARAN DEWAN PERWAKILAN RAKYAT DAERAH PROVINSI RIAU \\ (Studi Kasus Pada Sekwan Sebagai Mitra Kerja Komisi I Tahun Anggaran 2020)
}

\author{
${ }^{1}$ Ade Agus Hartanto, ${ }^{2}$ Muchid, ${ }^{3}$ M. Saeri \\ Fakultas IImu Sosial dan IImu Politik Universitas Riau \\ adeagushartanto@gmail.com, muchid@lecturer.unri.ac.id, m.saeri@lecturer.unri.ac.id, \\ RIAU - INDONESIA
}

\begin{abstract}
The purpose of the research is to find out the Budget Politics Of The Regional People'S Representative Council Of Riau Province At the Secretariat of the Council as a Working Partner of Commission I of Fiscal Year 2020. The research method used is qualitative and the data collection technique used in this study is Descriptive Qualitative. The results of this study showed in the budgeting process between the Riau Provincial Parliament, namely Commission I which is affiliated with the Secretary of the Council of one of the Regional Device Organizations of the Riau Provincial Government there are several issues where there are several interests in budgeting for Commission I and the Secretary of the Council for 2020 such as the budget in recruiting experts. The community is not very involved in the decision making, it should be input from the community into consideration for the DPRD. Some actors are very influential in making political decisions on budgets in 2020, both from the Executive and the Legislature.
\end{abstract}

Keywords: Budget Politics, Interests, Regional People's Representative Council

\begin{abstract}
Abstrak
Tujuan penelitian adalah untuk mengetahui Politik Anggaran Dewan Perwakilan Rakyat Daerah Provinsi Riau Pada Sekretariat Dewan Sebagai Mitra Kerja Komisi I Tahun Anggaran 2020. Metode penelitian yang digunakan adalah kualitatif dan teknik pengumpulan data yang digunakan dalam penelitian ini ialah Kualitatif Deskripstif. Hasil penelitian ini menunjukkan dalam proses penganggaran APBD antara DPRD Provinsi Riau yakni Komisi I yang berafiliasi dengan Sekretaris Dewan salah satu Organisasi Perangkat Daerah Pemerintah Provinsi Riau terdapat beberapa permasalahan dimana adanya beberapa kepentingan didalam penganggaran untuk Komisi I dan Sekretaris Dewan untuk tahun 2020 seperti anggaran dalam merekrut tenaga ahli. Masyarakat tidak terlalu dilibatkan didalam pengambilan keputusan tersebut, seharusnya masukan dari masyarakat menjadi pertimbangan bagi DPRD. Beberapa aktor sangat berpengaruh dalam mengambil keputusan politik anggaran pada tahun 2020, baik dari Eksekutif maupun Legislatif.
\end{abstract}

Kata Kunci: Dewan Perwakilan Rakyat Daerah; Kepentingan; Politik Anggaran

Open Access at:http://ojs.uho.ac.id/index.php/PUBLICUHO/index

Journal Publicuho is licensed under a Creative Commons Attribution 4.0 International License. 


\section{PENDAHULUAN}

Politik anggaran, secara umum dinilai sebagai domain pemerintah. Memasuki Era Demokrasi hal tersebut juga masih terbawa. Oleh pemerintah baik pusat atau daerah, partisipasi publik terkadang masih dinilai sebagai suatu ancaman. Upaya-upaya untuk meniadakan atau melakukan pembatasan terhadap anggaran publik ini oleh elit politik saat proses penganggaran adalah tindakan yang mengkhianati rakyat. Diciptakannya dalil yang menyebutkan bahwa rakyat tidak perlu untuk terlibat dan berpartisipasi dalam menentukan anggaran, sebab hal yang dipartisipasikan oleh rakyat tersebut telah disampaikan melalui Dewan Perwakilan Rakyat dan juga elit politik/eksekutif. Dalil ini merupakan suatu bentuk dari terjadinya penyimpangan yang disebabkan tidak ditatanya politik anggaran secara demokratis. Oleh sebab itu, elemen-elemen dengan formulasi politik baru penting untuk diperhatikan dalam rangka penentuan atau penetapan alokasi anggaran publik (Goraph, 2018).

Proses politik dalam penyusunan anggaran dapat terjadi baik secara vertikal ataupun horizontal. Secara horizontal terjadi antara kalangan partai yang duduk dalam fraksi-fraksi di DPRD. Masing-masing fraksi itu ingin menarik masyarakat agar dapat terpilih lagi dalam pemilihan yang akan datang. Caranya bermacam-macam, misalnya, dalam suatu dengar pendapat dengan eksekutif fraksi tertentu berusaha untuk mengusulkan kepada pemerintah kenaikan anggaran untuk sektor tertentu. Karena pemerintah belum mempunyai gambaran tentang jumlah kenaikan atau bahkan pagu anggaran untuk tahun berikutnya, pihak pemerintah biasanya hanya menampung saja. Akan tetapi usulan ini sudah terekam di benak masyarakat luas melalui media massa, sehingga masyarakat menggagap bahwa kepentingannya telah diperjuangkan oleh fraksi yang bersangkutan yang tentu saja akan memperoleh angka prestasi secara politik (Susanto, 2012)

Pada prinsipnya, keputusan yang dibuat oleh pemerintah, sejatinya bertujuan untuk menangani berbagai permasalahan publik yang mencakup kepentingan masyarakat. kebijakan anggaran ini akan mudah dipahami jika letaknya berada di dalam kerangka perhelatan berbagai kepentingan, termasuk pada pemain atau aktor yang ada di dalam lingkaran sistem politik atau merupakan kelompok kepentingan yang berada di luar sistem politik dengan pengaruh yang kuat di arena yang merupakan sumber daya publik yang tengah diperebutkan. Dalam politik anggaran, peran masyarakat pada dasarnya ialah turut melakukan pengawasan terhadap bagaimana kebijakan anggaran tersebut bisa direalisasikan ke bentuk yang manfaatnya bisa di rasakan oleh masyarakat. Namun, pada kenyataannya di lapangan yang terlihat hanyalah minimnya keterbukaan dari anggaran yang telah dikelola dan cenderung penguasaannya hanya dimiliki oleh segelintir penguasa. Tentu saja kondisi seperti ini sangat meresahkan dan juga menimbulkan rasa khawatir, 


\section{Journal Publicuho}

ISSN2621-1351 (online), ISSN 2685-0729 (print)

Volume 4 Number 1 (February-April), (2021)pp.69-77

Accredited SINTA SK.NOMOR 28/E/KPT/2019

Open Access at:http://ojs.uho.ac.id/index.php/PUBLICUHO/index

DOI: 10.35817/jpu.v4i1.16331

karena tidak pahamnya masyarakat terhadap proses dan tata aturan anggaran. Selain itu, menggunakan pengetahuannya, penguasa lebih memilih untuk menyembunyikannya dari masyarakat. Situasi-situasi seperti inilah yang menyebabkan penyelewengan dana publik menjadi sangat rentan terjadi. anggaran yang pada mulanya direncanakan dan ditujukan untuk kesejahteraan masyarakat menjadi tidak tercapai dan dana tersebut beralih kepemilikan kepada pengambil keputusan sepihak yaitu di antaranya adalah oknum-oknum penguasa (Susanto, 2012).

APBD Riau tahun 2020 tersebut dengan rincian pendapatan direncanakan sebesar Rp 7,892 triliun terdiri dari PAD Rp 3,919 triliun atau sekitar Rp 49,66 persen dari total proyeksi pendapata TA 2020. Rencana penerimaan PAD akan diperoleh pendapatan pajak daerah Rp 3,365 triliun, retribusi daerah Rp21,399 miliar, hasil pengelolaan kekayaan daerah Rp 143,703 miliar dan lain PAD yang sah Rp388,888 miliar. Dana perimbangan mencapai Rp3,954 ttiliun atau 50,11 persen dari total pendapatan. Kemudian, Belanja tidak langsung Rp 4,196 triliun, turun Rp 1,176 triliun dibandingkan APBD 2019 Rp 5,376 triliun. Belanja bagi hasil Kabupaten/Kota Rp 1,517 triliun, naik Rp 95,142 miliar daribAPBD 2019 RP 1,422 triliun. Belanja langsung Rp 8,182 triliun, naik Rp 4,064 triliun atau 98,73 persen dari APBD 2019 sebesar Rp 4,117 triliun.

Terdapat minimal 13 buah Organisasi Perangkat Daerah yang menjadi mitra Komisi I DPRD Provinsi Riau dalam melakukan tugasnya sebagai lesgislator mulai dari budgeting, controlling sampai tahap evaluasi yang semua proses anggarannya sudah melalui tahap diskusi dengan komisi I terkait rasionalisasi, anggaran, urgensi anggaran dan dampak anggaran kepada masyarakat sebagai konstituen legislator. Dryzek menyebutkan bahwa Anggota DPRD pada umumnya, ketika pelaksanaan meloloskan rancangan APBD dilapangan melalui proses serta kondisi yang berada pada rasa sadar atau tidak bahwa prose situ telah melewatkan koridor demokrasi. Oleh Dryzek hal ini dikatakan sebagai demokrasi yang tidak inklusif melainkan lebih kearah ekslusif, maksudnya adalah bahwa jalan dari proses rumusan rancangan APBD ini nyaris bersih atau steril dari pengaruh politik (Dryzek, 1996). Hal ini kemudian berdampak pada terabaikannya kepentingan publik yang tidak memiliki kekuatan atau kelompok "the most powerless", yaitu kelompok yang lemah secara sosial, ekonomi, maupun politik, sebut saja kaum perempuan, orang lanjut usia, anak-anak dan orang miskin (Abdul Wahab, 2008). Selanjutnya, terdapat temuan baru oleh Johnson, yaitu bahwa tekanan dari legislative dapat direspon oleh birokrasi selama pembuatan kebijakan dan anggaran itu diproses. (Magner \& Johson, 1995)

Penganggaran sebagaimana yang disebutkan oleh Hyde dan Shafritz adalah suatu proses yang pelaksanaannya di lakukan oleh eksekutif, meski pada akhirnya hasil dari proses itu ditentukan kembali oleh legislative, sebab legislative memiliki power atau kekuasaan untuk 
dapat memutuskan bahwa pengajuan anggaran tersebut dapat di sahkan atau sebaliknya, yaitu usulan dari kelompok eksekutif tersebut tidak dapat disahkan atau ditolak (Shafritz \& Hyde, 2007). Dobell dan Ulrich menyebutkan legislative memiliki peran yang penting yaitu yang mewakili dari beragam kepentingan publik atau masyarakat, kemudian pemberdayaan pemerintah serta awas terhadap kinerja pemerintah. Melalui peran-peran penting ini maka legislatur memiliki kelebihan yang dapat digunakan untuk mempengaruhi berbagai kebijakan penting dari pemerintah (Dobell \& Martin, 2002).

Legislative tidak harus memiliki preferensi yang tidak berbeda dengan pemerintah atas kebijakan dan hal ini juga meliputi kebijakan anggaran. Sejauh ini, proses politik agar APBD dapat disahkan tidak terlepas dari adanya keterlibatan pihak elit baik itu pimpinan daerah Provinsi, kabupaten, kota atau bahkan DPRD. Di waktu kontrol kekuatan dari masyarakat yang melemah dan tidak dimilikinya keterikatan moral di antara para anggota dewan di konstituen masing-masing, maka hal ini akan menimbulkan banyak kerugian bagi masyarakat. Situasi ini kemudian semakin menjadi buruk dengan adanya fakta bahwa tingkat kepedulian dari struktur politik terhadap kesejahteraan masyarakat sangat minim. Agenda publik, kemungkinan telah dijadwalkan dan direncanakan dengan sebaik mungkin namun melalui proses politik dan korupsi politik hal ini dengan mudah dihilangkan dan diganti dengan agenda institusional yang muatannya adalah poltik. (La Porta, 1996). Agenda institusional ini merupakan bagian dari kristalisasi kepentingan politik koslektif dari birokrasi daerah ataupun partai politik itu sendiri.

\section{METODOLOGI}

Dalam tulisan ini, metode penelitian yang digunakan yaitu metode kualitatif. Cresswell berpendapat pendekatan kualitatif adalah metode untuk memahami masalah sosial dan manusia secara holistik dengan menggunakan suatu proses penyelidikan dan dibentuk secara rinci melalui susunan kata terhadap objek berupa orang dan pelaku yang diamati (Creswell, 2014) dengan pendekatan Studi kasus. Studi kasus merupakan metode penelitian yang memiliki sifat multi-perspectival analyses, yaitu peneltian yang analisanya dibutuhkan dari berbagai sudut pandang serta tidak hanya terfokus pada satu objek individu saja. Menurut Peneliti, Pendekatan studi kasus dianggap paling sesuai untuk meneliti bagaimana dinamika politik anggaran DPRD Provinsi Riau yang dispesialisasikan kepada Sekwan sebagai mitra Komisi I dalam penyusunan Anggaran dan Pendapatan Belanja Daerah (APBD) Provinsi Riau Tahun 2020 yang sudah dibahas pada penghujung 2019 lalu. 


\section{Journal Publicuho}

ISSN2621-1351 (online), ISSN 2685-0729 (print)

Volume 4 Number 1 (February-April), (2021)pp.69-77

Accredited SINTA SK.NOMOR 28/E/KPT/2019

Open Access at:http://ojs.uho.ac.id/index.php/PUBLICUHO/index

DOI: 10.35817/jpu.v4i1.16331

\section{HASIL DAN PEMBAHASAN}

\section{Politik Anggaran DPRD Provinsi Riau Komisi I dengan Sekretaris Dewan}

Politik anggaran merupakan bagian dari pelaksanaan tata kelola keuangan yang terdapat dalam Pasal 3 UU No.17 Thn 2003 yang menjelaskan sebagai berikut: Keuangan Negara dikelola secara tertib, taat pada perundang- undangan efisien, ekonomis, efektif, transparan dan bertanggungjawab dengan memperhatikan asas keadilan dan kepatutan. Ketentuan perundang- undangan tersebut secara limitatif telah meletakan siklus pengelolan keuangan negara/daerah yang dimulai dari (1) Perencanaan, (2) Pembahasan, (3) Pengesahan, (4) Penatausahaan, (5) pengawasan dan (6) pertanggungjawaban. Hal yang paling penting di dalam menata pengelolaan keuangan negara/daerah saat ini adalah ketertiban dan keterbukan dalam menerapkan asas-asas hukum beranggaran sehingga ada ketepatan waktu dalam melaksakaan siklus anggaran pada setiap tahun anggaran oleh pemerintah daerah dan DPRD.

Pada tahun 2019 lalu, Pemerintah Provinsi Riau sudah mengsahkan total Anggaran Pendapatan dan Belanja Daerah (APBD) Provinsi Riau Tahun 2020 sebanyak Rp 12,379 Triliun. Hal ini ditandainya dengan Gubernur Riau Syamsuar Menyampaikan Nota Pengantar Keuangan Raperda APBD Tahun Anggaran 2020 ke DPRD Riau dalam rapat Paripurna yang dipimpin oleh Wakil Ketua DPRD Riau Zukri Misran didampingi Wakil Ketua DPRD Riau Asri Auzar dan trennya APBD Riau mengalami kenaikan sebanyak 30,38 persen dari APBD 2019 Rp 9,494 triliun (Riau.go.id, 2019)

APBD Riau tahun 2020 tersebut dengan rincian pendapatan direncanakan sebesar Rp 7,892 triliun terdiri dari PAD Rp 3,919 triliun atau sekitar Rp 49,66 persen dari total proyeksi pendapata TA 2020. Rencana penerimaan PAD akan diperoleh pendapatan pajak daerah Rp 3,365 triliun, retribusi daerah Rp21,399 miliar, hasil pengelolaan kekayaan daerah Rp 143,703 miliar dan lain PAD yang sah Rp388,888 miliar. Dana perimbangan mencapai Rp3,954 ttiliun atau 50,1 1 persen dari total pendapatan. Kemudian, Belanja tidak langsung Rp 4,196 triliun, turun Rp 1,176 triliun dibandingkan APBD 2019 Rp 5,376 triliun. Belanja bagi hasil Kabupaten/Kota Rp 1,517 triliun, naik Rp 95,142 miliar dari APBD 2019 RP 1,422 triliun. Belanja langsung Rp 8,182 triliun, naik Rp 4,064 triliun atau 98,73 persen dari APBD 2019 sebesar Rp 4,117 triliun(Riau.go.id, 2019).

Tahun 2020, anggaran APBD Riau tercatat sebesar Rp 7,892 triliun. anggaran ini include didalamnya belanja dan Anggaran mitra Komisi I DPRD Provinsi Riau yang terdiri dari 13 Organisasi Perangkat Daerah: Organisasi Perangkat Daerah Mitra KOmisi I DPRD Prov Riau disajikan pada Tabel 1. 
Tabel 1. Organisasi Perangkat Daerah Mitra Komisi I DPRD Prov. Riau

\begin{tabular}{cl}
\hline No & \multicolumn{1}{c}{ Organisasi Perangkat Daerah } \\
\hline 1 & Biro Umum \\
\hline 2 & Biro Hukum \\
\hline 3 & Biro Pemerintahan \\
\hline 4 & Biro Organisasi \\
\hline 5 & Biro ADPIM \\
\hline 7 & Diskominfotik \\
\hline 8 & Kesbangpol Prov. Riau \\
\hline 9 & BKD Prov. Riau \\
\hline 10 & BPSDM \\
\hline 11 & Satpol PP \\
\hline 12 & Badan Penghubung Prov. Riau \\
\hline 13 & Sekretaris Dewan \\
\hline & Sumber: Sekretariat DPRD Provinsi Riau, 2020
\end{tabular}

Terdapat minimal 13 buah Organisasi Perangkat Daerah yang menjadi mitra Komisi I DPRD Provinsi Riau dalam melakukan tugasnya sebagai lesgislator mulai dari budgeting, controlling sampai tahap evaluasi yang semua proses anggarannya sudah melalui tahap diskusi dengan komisi I terkait rasionalisasi, anggaran, urgensi anggaran dan dampak anggaran kepada masyarakat sebagai konstituen legislator.

\section{Sekretaris Dewan Sebagai Mitra Komisi I DPRD Provinsi Riau}

Sekretaris Dewan mempunyai beberapa tugas pokok dan fungsi. Sebagai mitra kerja Komisi I DPRD Provinsi Riau beberapa tugas pokok dan juga fungsi tersebut tercantum dalam peraturan daerah provinsi riau Nomor 1 tahun 2014 tentang organisasi dan tata kerja sekretariat daerah dan sekretariat DPRD Provinsi Riau. Dalam peraturan ini ditegaskan bahwa Sekretariat Daerah mempunyai tugas dan kewajiban untuk membantu gubernur dalam menyusun kebijakan dan mengoordinasikan dinas daerah, badan dan lembaga teknis daerah. Beberapa tugas Sekretariat DPRD di antaranya adalah memastikan terselenggaranya administrasi kesekretariatan, administrasi keuangan, serta mendukung terlaksananya tugas dan fungsi DPRD, dan menyediakan serta mengoordinasikan tenaga ahli yang diperlukan oleh DPRD sesuai dengan kemampuan keuangan daerah, dan tugas memimpin sekretariat daerah, membantu gubernur dalam menyusun kebijakan dan mengoordinasikan dinas daerah, badan dan lembaga teknis daerah.

a. Sekretariat DPRD dipimpin oleh seorang Sekretaris Dewan dan secara teknis operasional berkedudukan di bawah dan bertanggung jawab kepada Pimpinan Dewan Perwakilan Rakyat Daerah dan secara administratif bertanggung jawab kepada Gubernur melalui Sekretaris Daerah. Dari uraian tersebut diatas maka tugas pokok dari seorang yang menjabat sebagai Sekretaris DPRD di antaranya yaitu: a. melakukan koordinasi pada rumusan dan susunan yang terkait dengan visi juga misi, 


\section{Journal Publicuho}

ISSN2621-1351 (online), ISSN 2685-0729 (print)

Volume 4 Number 1 (February-April), (2021)pp.69-77

Accredited SINTA SK.NOMOR 28/E/KPT/2019

Open Access at:http://ojs.uho.ac.id/index.php/PUBLICUHO/index DOI: 10.35817/jpu.v4i1.16331

kemudian rencana kerja tahunan dan rencana strategis, serta penetapan terhadap kinerja di lingkup Sekretariat DPRD

b. Melakukan penyelenggaraan pengaturan, pengawasan, pembinaan, dan pengendalian serta bimbingan pelaksanaan tugas Sekretariat DPRD

c. diselenggarakannya koordinasi, dan sinkronisasi dalam berbagai tugas yang dilaksanakan oleh Sekretariat DPRD yang bekerjasama dengan SKPD dan instansi terkait;

d. terlaksananya koordinasi dan sinkronisasi, serta konsultasi di dalam pelaksanaan tugas;

e. Tersedian dan terkoordinasinya kelompok ahli atau pakar sesuai dengan ketentuan yang ditetapkan yang keberadaannya dibutuhkan oleh DPRD.

f. Adanya koordinasi dalam rencana kegiatan alat kelengkapan DPRD

g. melakukan koordinasi terhadap terselenggaranya pengelolaan administrasi keuangan, juga kepegawaian serta barang yang menjadi milik daerah di ranah lingkungan Sekretariat DPRD;

h. melakukan koordinasi terkait terselenggaranya berbagai rapat kunjungan kerja, reses, konsultasi, workshop/bimbingan tekhnis, konsentrasi, dengar pendapat (Hearing), ataupun kegiatan DPRD lainnya;

i. memonitoring dan mengevaluasi pelaksanaan tugas Sekretariat DPRD;

j. melaksanakan pelaporan terhadap pelaksanaan tugas administratif kepada Walikota sebagai pertanggung jawaban melalui Sekretaris Daerah;

k. melakukan pelaporan terkait dengan terlaksananya kewajiban yang menjadi tugas kepada Walikota melalui Sekretaris Daerah yang berhubungan dengan pelaksaan tugas berupa administrasi keuangan, barang milik daerah maupun kepegawaian

L. melakukan tugas -tugas lainnya yang diberikan oleh atasan dengan memperhatikan kesesuaian dari tugas pokok dan fungsi .

Untuk dapat melaksanakan hal-hal yang menjadi tugas pokok seperti yang disampaikan diatas maka fungsi yang dimiliki oleh Sekretaris DPRD di antaranya adalah:

a. menyelenggarakan administrasi kesekretariatan DPRD:

b. menyelenggarakan administrasi keuangan DPRD;

c. menyelenggarakan rapat-rapat DPRD; dan

d. menyediakan serta mengkoodinasikan tenaga ahli yang keberadaannya dibutuhkan oleh DPRD.

\section{Kepentingan Politik}

Alokasi-alokasi penganggaran pada Komisi I dengan Sekretaris Dewan yang sudah ditentukan harus dimanfaat secara maksimal, anggaran ini harus sebagai penunjang kinerja 
bagi Komisi I dengan Sekretaris Dewan dalam menjalankan tugas pokok dan fungsinya. Ini akan menjadi pertanggungjawaban kepada masyarakat dengan menghadirkan transparansi anggaran yang sudah ditetapkan.

Dalam proses pembahasan dan penyusunan anggaran ini tentu akan dipengaruhi beberapa kepentingan poilitik seperti dalam pengadaan tenaga ahli yang akan digunakan oleh setiap fraksi, komisi hingga anggota dewan, tentunya DPRD Provinsi Riau ingin masingmasing anggota DPRD bisa merekrut tenaga ahli sesuai dengan kebutuhannya sedangkan anggaran ini sangat terbatas dan sudah ditentukan. Ini menjadi perseolan dalam pembahasannya sehingga terjadi tarik menarik kepentingan.

\section{KESIMPULAN}

Berdasarkan hasil penelitian dan pembahasan terkait politik anggaran pada Dewan Perwakilan Rakyat Daerah Provinsi Riau dengan mitra kerjanya yakni Sekretaris Dewan pada pembahasan dan penyusunan anggaran Tahun 2020 terdapat beberapa permasalahan, ini dimulai sejak dalam proses pembahasan pada tahun 2019 hingga pengesahannya. Pembahasan anggaran untuk tahun 2020 terjadi tarik menarik antara Dewan Perwakilan Rakyat Daerah Provinsi Riau yakni Komisi I Bidang Pemerintahan dan Hukum dengan Sekretaris Dewan. Adanya kepentingan atau aktor-aktor politik yang sangat berpengaruh dalam pembahasan penganggaran ini sangat dominan baik itu dari eksekutif maupun dari legislatifnya, anggaran ini berpotensi lebih memihak kepada kepentingan kelompok tertentu. Seharusnya dalam proses penganggaran ini masyarakat harus dilibatkan dengan mendengar dan memproses masukan-masukan terkait kebutuhan masyarakat itu sendiri.

Proses pembahasan terkait penganggaran untuk tahun 2020 antara Komisi I DPRD Provinsi Riau dengan Sekretaris Dewan harus transparan agar masyarakat harus mengetahui terkait alokasi-alokasi dana penganggaran untuk dilaksanakan atau diimplementaasikan. Tentunya alokasi-alokasi dana ini harus bertujuan untuk kepentingan bersama-sama tanpa harus memihak dan menguntung kelompok tertentu. Selain itu, dengan sudah ditetapkan anggaran komisi I dengan Sekretaris Dewan, maka diharapkan kepada Sekretaris Dewan DPRD Provinsi Riau harus bekerja dengan maksimal dengan tugas, pokok dan fungsinya yang sudah ditentukan. 


\section{Journal Publicuho}

ISSN2621-1351 (online), ISSN 2685-0729 (print)

Volume 4 Number 1 (February-April), (2021)pp.69-77

Accredited SINTA SK.NOMOR 28/E/KPT/2019

\section{DAFTAR PUSTAKA}

Abdul Wahab, S. (2008). Analisis Kebijakan Publik, Teori dan Aplikasinya. Brawijaya Universitas Press

Creswell, J. W. (2014). Research design: Qualitative, quantitative, and mixed methods approaches (4th ed). SAGE Publications

Dobell, P., \& Martin, U. (2002). Parliament's performance in the budget process: A case study. Policy Matters, 3(2): 1-24. http://www.irpn.org diakses, 7 April 2009

Dryzek, J. S. (1996). Political Inclusion and the Dynamics of Democratization. American Political Science Review, 90(3), 475-487. https://doi.org/10.2307/2082603

Goraph, F. A. (2018). Perlukah Kesetaraan dalam Politik Anggaran? [Preprint]. Open Science Framework. https://doi.org/10.31219/osf.io/kub82

Humas Provinsi Riau"Total APBD Riau Tahun 2020 Rp 12,379 Triliun". Dalam https://www.riau.go.id/home/content/2019/11/04/8202-total-apbd-riau-tahun-2020-rp12379-triliun.Diakses pada tanggal 01 Februari 2021

La Porta, R. (1996). Expectations and the Cross-Section of Stock Returns. The Journal of Finance, 51 (5), 1715-1742. https://doi.org/10.1111/j.1540- 6261.1996.tb05223.x

Magner, N., \& Johson, Gary. G. (1995). Municipal Officials' Reactions To Justice In Budgetary Resource Allocation. Public Administration Quarterly, 18(4), 439- 456. JSTOR. www.jstor.org/stable/40861636

Peraturan daerah provinsi riau Nomor 1 tahun 2014 tentang organisasi dan tata kerja sekretariat daerah dan secretariat DPRD Provinsi Riau

Shafritz, J. M., \& Hyde, A. C. (Eds.). (2007). Classics of public administration (6th ed). Thomson Wadsworth.

Susanto, A. (2012). Politik Anggaran Pemerintah Provinsi Riau (Studi Kasus Pada Kontroversi Pembangunan Tugu Zapin Di Kota Pekanbaru Tahun 2011). Repositori Universitas Riau. https://repository.unri.ac.id/jspui/bitstream/123456789/616/1/JURNAL\%2 OAGUS\%2OSUSANTO.pdf

Undang-undang No.17 Tahun 2003 Tentang Keuangan Negara 